\title{
Prevalence and Clinical Aspects of Otodectes cynotis Infestation in Dogs and Cats in the Semi-arid Region of Paraíba, Brazil
}

\author{
Juliana Trajano da Silva', Larissa Claudino Ferreira', Mikaelly Mangueira Fernandes' \\ Larissa do Nascimento Sousa ${ }^{2}$, Thais Ferreira Feitosa', Fabio Ribeiro Braga ${ }^{3}$, \\ Arthur William de Lima Brasil ${ }^{4} \&$ Vinícius Longo Ribeiro Vilela ${ }^{1,2}$
}

\begin{abstract}
Background: Infestation by Otodectes cynotis is one of the main causes of external otitis in small animals, causing great disconfort and predisposition to secondary bacterial or fungal infections, with relevant importance in the small animal medicine. In dogs, a small number of this parasite in the ears may cause inflammation, while in cats, otoacariasis accounts for half of the external otitis cases. Due to the insufficiency of data about the prevalence of this disease in the Northeast region of Brazil, the purpose of the present study was to evaluate the prevalence and clinical aspects of $O$. cynotis in dogs and cats from the Semi-arid region of Paraíba, Brazil.

Materials, Methods \& Results: The research was conducted in the municipality of Sousa, Paraíba State, Brazil. A total of 102 dogs and 152 cats had their external ear canals examined by bilateral otoscopy, using an otoscope with a veterinary cone that allows inspection of the external ear canal. Parasitological swabs were also used to determine the prevalence of parasitism by Otodectes cynotis. Samples collected in swabs were stored in a 70\% alcohol preservative solution and sent to the Laboratory of Veterinary Parasitology, in wich were examinated on direct research, using microscopes in the 10x objective (magnification of 100x). In all animals, clinical examinations were performed and their owners answered an epidemiological questionnaire to collect information about food and sanitary management. During the clinical examination, characteristics such as otopodal reflex, and the presence of pruritus and/or cerumen were also evaluated. The prevalence of dogs and cats positive for O. cynotis was 33.3\% (34/102) and 52.6\% (80/152), respectively. Bilateral infestations occurred in $52.9 \%(18 / 34)$ of the positive dogs. Most of the positive animals showed evidence of the mite in both tests, Otoscopy + Swab [dogs: 58.8\% (20/34) and cats: 66.2\% (53/80)].

Discussion: A high prevalence of Otodectes cynotis infestation was observed in dogs (33.3\%) and even higher prevalence in cats $(52.6 \%)$, both are higher than it was expected. The diagnosis methods were effective for detecting infestation by this parasite, and the parasitological swab resulted in higher diagnosis rate than the otoscopy. The use of two diagnosis methods resulted in a greater number of positive diagnoses, explaining the high prevalence found in the present study. A higher prevalence was observed for animals that had contact with other animals. The direct form is the most accepted mode of transmission of Otodectes sp. and close confinement of animals was considered the main associated factor for frequent reinfestation by the mite. For dogs, the presence of cerumen and pruritus were seen as $O$. cynotis infestation factors. Considering dogs, in the clinical examination, the presence of pruritus was significantly associated with the occurrence of parasitism. This association can be explained because $O$. cynotis is very active within the ear canals of parasitized animals, causing great annoyance and pruritus. No statistically significant risk factors were found for cats, but it was observed that adults had higher levels of infestation when compared to young cats, wich was not expected, as the literature commonly reports that young cats have higher levels of infestation. This can be explained by the confinement and the usual direct contact by different cats, increasing the occurrence of the parasite. In cats, the clinical examinations showed that the presence of otopodal reflex was significantly associated $(P<0.2)$ with the parasitism occurrence $(55.4 \%$; 66/119). The evaluation of this reflex has been considered as one of the symptoms of otocariosis.
\end{abstract}

Keywords: mites, otitis, otocariosis.

DOI: $10.22456 / 1679-9216.99156$

Accepted: 17 March 2020

Published: 14 April 2020

${ }^{1}$ Departamento de Medicina Veterinária, Instituto Federal da Paraíba (IFPB), Sousa, PB, Brazil. ${ }^{2}$ Programa de Pós-Graduação em Ciência Animal, Universidade Federal de Campina Grande (UFCG), Patos, PB, Brazil. ${ }^{3}$ Programa de Pós-Graduação em Ciência Animal, Universidade de Vila Velha (UVV), Vila Velha, ES, Brazil. ${ }^{4}$ Departamento de Medicina Veterinária, Universidade Federal de Rondônia (UNIR), Rolim de Moura, RO, Brazil. CORRESPONDENCE: V.L.R. Vilela [vinicius.vilela@ ifpb.edu.br]. Laboratório de Parasitologia Veterinária, Instituto Federal da Paraíba (IFPB). Av. Tancredo Neves s/n. CEP 58800-970 Sousa, PB, Brazil. 


\section{INTRODUCTION}

Otodectes cynotis is the major cause of parasitic otitis, infesting the external ear canal and adjacent skin of dogs, cats, foxes and ferrets, causing intense irritation [3]. Otitis externa is associated with the presence of $O$. cynotis, which feed on superficial debris and cerumen, irritating the ear canal, causing hypersensitivity, erythema, pruritus and a dark ceruminous secretion $[6,19]$.

In dogs, a small number of $O$. cynotis in the ears may cause inflammation, expel mites from the ear canals or be killed by exudate [9]. The $O$. cynotis is responsible for 5 to $10 \%$ of cases of external otitis mainly in dogs, but also in cats, with no predisposing sex or breed in either species [22].

Kittens are infested frequently by the mother and some animals may be asymptomatic carriers [21]. The illness is currently reported worldwide in felines, especially in confined conditions [4].

Diagnosis of $O$. cynotis infestation can be performed using different methods, such as indirect inspection using an otoscope, through which the mite is observed in the meatus of the infested animal or by collection of ear secretions for visualization of the mites using optical microscopy [28].

Although otoacariasis is a common disease in Brazil [23], there have been no studies on the prevalence of infestation by $O$. cynotis in the Northeast region. Thus, the objective of the present study was to evaluate the prevalence of Otodectes cynotis infestation in dogs and cats from de Semi-arid region of Paraíba State, Brazil, and correlate the infestation status with clinical and epidemiological aspects.

\section{MATERIALS AND METHODS}

\section{Georeferencing}

The research was conducted in the municipality of Sousa, the semi-arid region of Paraíba State, Brazil (Lat. 0645'33" S; Long. 38 13 '41” W). This municipality has a territorial area of $738,547 \mathrm{~km}^{2}$ and 69,161 inhabitants [12]. The region has a semi-arid climate, with an annual mean temperature of $26.6^{\circ} \mathrm{C}$ [13].

\section{Animal sampling and epidemiological questionnaires}

To determine the prevalence of infestation, the minimum number of dogs and cats to be examined was calculated as 98 . This number was calculated considering an expected prevalence of 50\% for otodectic mange, since there are no reports of the prevalence of infesta- tion by this ectoparasite in small animals, in northeast Brazil. A minimum confidence interval of $95 \%$ was also considered, assuming a statistical error of $10 \%$ [27]. In total, 102 dogs and 152 cats were examined from April to December 2017. Animals of both sexes, different breeds and age groups were selected, independent of clinical signs of otopathies, from households located in the municipality of Sousa, Semi-arid region of Paraíba, Brazil.

Simultaneously, investigative questionnaires were applied to all animal guardians, containing objective and subjective questions about sanitary management, feeding and contact with other animal species.

\section{Clinical and laboratorial analysis}

Bilateral otoscopy was performed using an otoscope ${ }^{1}$ with a veterinary cone that allows inspection of the external ear canal. Animals were restrained and positioned preferably in lateral decubitus or in a station, and the examination was carried out bilaterally, with the observer parallel to the body of the animal, as previously reported [27]. Otoscopic examinations were performed by the same researcher throughout the study. After each use, the cones were disinfected with $2 \%$ Chlorhexidine $^{2}$ solution.

To increase the reliability of diagnosis independently of otoscopy results, the parasitological swab technique was performed. For this, $\mathrm{a} \mathrm{swab}^{2}$ was introduced into each ear and posteriorly rotated $360^{\circ}$ clockwise to collect otological secretion samples. After collection, swabs were stored in a $70 \%$ alcohol preservative solution, duly identified and sent to the Laboratório de Parasitologia Veterinária (LPV), Veterinary Hospital, Instituto Federal da Paraíba (IFPB), Sousa-PB, where microscopic ${ }^{3}$ examinations were carried out using a 10X objective (100X magnification).

Clinical characteristics, such as pinnal-pedal reflex, auricular pavilions, and the presence of pruritus and/or cerumen were also evaluated.

\section{Statistical analysis}

Based on the epidemiological questionnaires, possible associations between questionnaire data (independent variable) and test results (dependent variable) were evaluated. This evaluation was carried out twice. An initial univariate exploratory analysis was performed in order to select variables that presented $P \leq 0.2$ using the chi-squared test or Fisher's exact test. These variables were then subjected to multivariate analysis through multiple logistic regression at a significance level of 5\% [11]. The 
adjustment of the final model was performed using Hosmer and Lemeshow coefficients, where for a good fit of the stipulated value was $P \geq 0.05$. Collinearity of independent variables was determined by correlation analysis, and when presenting a correlation coefficient $<0.9$, variables were eliminated according to biological plausibility [5]. Data analyses were performed using IBM SPSS (version 23) ${ }^{4}$.

\section{RESULTS}

Among the 255 animals examined for $O$. cynotis, 106 were positive in at least one of the tests performed, resulting in a prevalence of $41.5 \%$. In dogs, the prevalence was $33.3 \%$ (34/102), and in cats was 52.6\% (119/152). The percentage effectiveness of diagnosis methods in dogs and cats, were $76.5 \%(26 / 34)$ and $68.8 \%$ (55/80) for otoscopy + swab; $14.7 \%$ (5/34) and 25\% (20/80) for swab; and 8.8\% $(3 / 34)$ and $6.2 \%(5 / 80)$ for otoscopy, respectively.

Univariate analysis for risk factors in dogs revealed that $85.3 \%$ (29/34) of positive animals were of non-defined breed (NDB). Among dogs with otocariasis, 97.1\% (33/34) had contact with animals of the same species. Cerumen accumulation was present in $67.6 \%$ (23/34) and pruritus in $82 \%(30 / 34)$ of the animals with a positive diagnosis (Table 1).

Regarding the ages of positive cats, $56.1 \%$ (23/41) were up to twelve months-old, $40 \%$ (18/45) were between 13 and 36 months-old, and $48.8 \%$ $(39 / 66)$ were $>36$ months-old. Among those that had contact with other animals, $48.6 \%$ (55/113) were positive, and among those that had contact with other cats, $55.5 \%$ (65/117) were positive. Pinnal-pedal reflex was found in 119 cats, but only 55.4\% (66/119) of wich were positive cats (Table 2 ).

Risk factors for O. cynotis infestation in dogs, identified by multiple logistic regression analysis, are shown in Table 3. Cerumen and pruritus were seen as O. cynotis infestation factors in dogs, although none were found in cats.

Table 1. Univariate analysis for infestation by Otodectes cynotis in domiciled dogs from semi-arid region of Paraíba, Brazil.

\begin{tabular}{|c|c|c|c|c|}
\hline Variable & Category & $\mathrm{N}$ total & $\%$ Positive & $P<0.2$ \\
\hline \multirow{2}{*}{ Breed } & No & 28 & $5(17.8)$ & \multirow{2}{*}{0.059} \\
\hline & Yes & 74 & $29(39.1)$ & \\
\hline \multirow{2}{*}{ Contact dogs } & No & 23 & $1(4.3)$ & \multirow{2}{*}{$<0.001$} \\
\hline & Yes & 79 & $33(41.7)$ & \\
\hline \multirow{3}{*}{ Food } & Ration & 12 & $0(0)$ & \multirow{3}{*}{0.010} \\
\hline & Ration and homemade food & 10 & $6(60)$ & \\
\hline & Homemade food & 80 & $28(35)$ & \\
\hline \multirow{2}{*}{ Cerumen } & No & 68 & $11(23.5)$ & \multirow{2}{*}{$<0.001$} \\
\hline & Yes & 34 & $23(67.6)$ & \\
\hline \multirow{2}{*}{ Pruritus } & No & 65 & $4(11.8)$ & \multirow{2}{*}{$<0.001$} \\
\hline & Yes & 37 & $30(88.2)$ & \\
\hline \multirow{3}{*}{ Localization } & No & 71 & $4(11.8)$ & \multirow{3}{*}{$<0.001$} \\
\hline & One ear & 13 & $12(35.3)$ & \\
\hline & Both ears & 18 & $18(52.9)$ & \\
\hline
\end{tabular}

Table 2. Univariate analysis for Otodectes cynotis infestation in domiciled cats in the semi-arid region of Paraíba, Brazil.

\begin{tabular}{ccccc}
\hline Variable & Category & N total & \%Positive & $P<0.2$ \\
\hline \multirow{2}{*}{ Age (months) } & $\leq 12$ & 41 & $23(56.1)$ & \\
& $13-36$ & 45 & $18(40)$ & 0.124 \\
& $>36$ & 66 & $39(59.1)$ & \\
\hline \multirow{2}{*}{ Contact with other animals } & No & 39 & $25(64.1)$ & \multirow{2}{*}{0.096} \\
& Yes & 113 & $55(48.6)$ & \\
\hline \multirow{2}{*}{ Contact with cats } & No & 35 & $15(42.8)$ & \multirow{2}{*}{0.187} \\
\hline Pinnal-pedal reflex & Yes & 117 & $65(55.5)$ & \\
& No & 33 & $14(42.4)$ & \multirow{2}{*}{0.184} \\
\hline
\end{tabular}


J.T. Silva, L.C. Ferreira, M.M. Fernandes, et al. 2020. Prevalence and Clinical Aspects of Otodectes cynotis Infestation in Dogs and Cats

Table 3. Multiple logistic regression analysis and risk factors for infestation by Otodectes cynotis in domiciled dogs in the semi-arid region of Paraíba, Brazil.

\begin{tabular}{cccccccc}
\hline Variable & RC & SE & Wald & DF & Odds ratio & CI & $P$ \\
\hline cerumen & 1.434 & 0.684 & 4.401 & 1 & 4.197 & {$[1.099-16.026]$} & 0.036 \\
pruritus & 3.761 & 0.685 & 30.187 & 1 & 42.986 & {$[11.238-164.431]$} & $<0.0001$ \\
\hline
\end{tabular}

Hosmer and Lemeshow's test: Chi-squared $=0.306$; degrees of freedom $=2 ; P=0.858 . \mathrm{RC}=$ regression coefficient; $\mathrm{SE}=$ standard error; $\mathrm{DF}=$ degrees of freedom; $\mathrm{CI}=$ Confidence Interval.

\section{DISCUSSION}

Otitis is an inflammatory process of the ear and is classified according to its location as external, middle or internal. Prognosis and treatment differ according to type and associated etiology [20]. Otocariosis is very distressing to small animals, causing much discomfort in the auditory canal. Otodectes cynotis primarily affected dogs, but is increasingly being diagnosed in cats, and responsible for at least half of feline otitis externa cases [21]. In spite of having a cosmopolitan distribution, studies associating the clinical and epidemiological aspects of infestation by this mite are still scarce. The present study is the first to examine the prevalence and risk associated to $O$. cynotis infestation in dogs and cats in Northeastern Brazil.

A high prevalence of $O$. cynotis infestation was observed in dogs (33.3\%). Other researchers identified $6 \%$ (15/250) positivity in dogs, independent of presenting a hearing complaint [25]. In addition, there was a high prevalence in cats $(52.6 \%)$, higher than results reported by other authors, which ranged from $6.2 \%$ to $37 \%$ of the animals analyzed $[1,15,17,23]$.

Both methods were effective for identifying mite infestation, and the parasitological swab method demonstrated diagnostic superiority when compared to otoscopy. Thus, the need for a complementary examination is highlighted when otoscopy is negative [14]. Even with less sensitivity, otoscopy for the detection of $O$. cynotis is useful in practice, especially considering the immediacy of diagnosis. The use of two diagnosis methods results in a greater number of positive diagnoses, explaining the high prevalence found in the present study.

No predisposition to breed was described for animals positive for O. cynotis infestation [26], confirming our results, where observed higher levels of infestation in NDB animals, probably due to variables such as poor environmental conditions, street access and contact with other animals.
A higher prevalence was observed for animals that had contact with other animals. The direct form is the most accepted mode of transmission of Otodectes sp. [9], and living with other animals is a preponderant factor for the transmission of parasitism [10]. Therefore, close confinement of animals was considered the main reason for frequent reinfestation by the mite, so some factors may be directly related to prevalence: frequent acquisition of animals, frequency of environment cleaning and lack of triage and quarantine, which influence the direct transmission of the mite [16,24,29].

Considering dogs, in the clinical examination, the presence of pruritus was significantly associated with the occurrence of parasitism. Pruritus can be observed in the ears in $80 \%(12 / 15)$ of animals with Otodectes sp. [25]. This association can be explained because $O$. cynotis is very active within the ear canals of parasitized animals, causing great annoyance and pruritus. Likewise, there was a significant relationship between the presence of secretion and parasitism. When parasitized by the mite $O$. cynotis, the external ear canal presents a dark colored secretion, often hardened, and may vary due to secondary bacterial or fungal infection $[2,10,26]$.

Bilateral infestations occurred in $52.9 \%$ $(18 / 34)$ of dogs, similar to that observed by other researchers $[8,26]$. The high prevalence of bilateral otocariasis is justified by the unilateral infestations being less frequent, since they usually occur when the time elapsed from the beginning of the infestation was insufficient for the mites to have reached both ears, or, if they had already been there, some change in the conduit environment (such as bacterial or fungal secondary infection) caused death or migration of the parasites [29].

Although no risk factors were found for mite infestation in cats, it was observed that adults had higher levels of infestation when compared to young cats $(P \leq 0.2)$. These results differ from other reports, which indicated a direct relationship of the occurrence 
of parasitism in young cats [7]. The higher occurrence of parasitism in young animals occurs due to the absence of a state of immunological resistance, which was only observed in adult animals [14]. However, the data presented here suggest that, although the development of acquired immunity with age is an important factor in resistance to parasitic infestations, other factors show a greater importance in the occurrence of parasitism, such as close confinement and direct contact, which justify the occurrence of parasitism in adult animals in the studied populations.

In the clinical examinations of cats, the presence of otopodal reflex was significantly associated $(P<0.2)$ with the occurrence of parasitism $[55.4 \%$ $(66 / 119)]$. The association of this reflex with parasitism was not observed [26]. However, this reflex had already been considered as one of the symptoms of otocariosis in the following terms: "In the manipulation of the auricular pavilion, it is possible to induce the triggering of the pinnal-pedal reflex" [14]. The evaluation of this reflex was also recommended as a diagnostic technique for otodectic mange in cats, whose authors observed a reflex in up to $93 \%$ of animals with positive results obtained through otoscopical and parasitological examinations [18].

\section{CONCLUSION}

It was high the prevalence of Otodectes cynotis infestations in dogs and cats in the Semi-arid region of Paraíba State. The combined use of the Otoscopy + Parasitological Swab method is more effective for diagnosis of such infestations. For dogs, presence of cerumen and pruritus are considered infestation factors.

By controlling infestations, mainly with the use of creams and therapeutic compounds, it is possible to treat symptomatic animals which present cerumen, pruritus, and pinnal-pedal reflex. Moreover, positive Otoscopy + Parasitological Swab tests can diagnose asymptomatic infestation sources.

\section{MANUFACTURERS \\ ${ }^{1}$ WiscMed LLC. Madison, WI, USA. \\ ${ }^{2}$ Rioquímica S.A. São José do Rio Preto, SP, Brazil. \\ ${ }^{3}$ Opto-Edu Co. Ltd. Beijing, China. \\ ${ }^{4}$ IBM Corp. Armonk, N.Y., USA.}

Ethical Approval. This research was approved by the Committee on Ethics in the Use of Animals (CEUA), of the IFPB, approval number 01250.012779/2017-83.

Declaration of interest. The authors report no conflicts of interest. The authors alone are responsible for the content and writing of the paper.

\section{REFERENCES}

1 Akucewich L.H., Philman K., Clark A., Gillespie J., Kungle G., Nicklin C.F. \& Greiner E.C. 2002. Prevalence of ectoparasites in a population of feral cats from North Central Florida during the summer. Veterinary Parasitology. 109(1): 129-139.

2 August J.R. 1988. Otitis externa, a disease of multifactorial etiology. Veterinary Clinics of North America: Small Animal Practice. 18(1): 731-742.

3 Bowman D.D. 2006. Parasitologia Veterinária de Georgis. 8.ed. São Paulo: Manole, pp. 68-69.

4 Dantas-Torres F. \& Otranto D. 2014. Dogs, cats, parasites, and humans in Brazil: opening the black box. Parasite \& Vectors. 7(1): 22- 46.

5 Dohoo I.R., Ducrot, C., Fourichon C., Donald A. \& Hurnik D. 1997. An overview of techniques for dealing with large number so find dependent variables in epidemiologic studies. Preventive Veterinary Medicine. 29(3): 221-239.

6 Farkas R., Germann T. \& Szeidemann Z. 2007. Assessment of the ear mite (Otodectes cynotis) infestation and the efficacy of an imidacloprid plus moxidectin combination in the treatment of otoacariasis in a Hungarian cat shelter. Parasitology Research. 101(1): 35-44.

7 Frost R.C. \& Beresford-Jones W.P. 1958. Otodectic mange in the dog. Veterinary Record. 70(37): 740-742.

8 Gomes A.P.M., Souza Neto A.F., Loss Z.G. \& Rodriguez O.D. 1998. Sarna auricular assintomática em cães. Revista Brasileira de Medicina Veterinária. 20(4): 175-176.

9 Gotthelf L.N. 2000. Primary causes of ear disease. In: Gotthelf L.N. (Ed). Small Animal Ear Diseases: An Illustrated Guide. Philadelphia: Saunders, pp.87-97.

10 Harvey R.G., Harari J. \& Delauche A.J. 2004. Doenças do ouvido em cães e Gatos. Rio de Janeiro: Revinter, pp.72105.

11 Hosmer D.W. \& Lemeshow S. 2000. Applied logistic Regression. 2nd edn. New York: John Wiley \& Sons, pp.31-33. 
12 Instituto Brasileiro e Geografia e Estatística (IBGE). 2018. Sistema IBGE de Recuperação Automática. Disponível em:<https://sidra.ibge.gov.br/tabela/6579\#resultado >. [Accessed online in January 2019].

13 Instituto Nacional de Meteorologia (INMET). 2010. Normais Climatológicas do Brasil. Disponível em: <http:// www.inmet.gov.br/portal/index.php?r=clima/normaisClimatologicas $>$. [Accessed online in March 2019].

14 Larsson C.E. 1989. Dermatologia veterinária. I. Dermatites parasitárias dos carnívoros domésticos: sarnas sarcóptica, notoédrica e otoacaríase. Comunicações Científicas da Faculdade de Medicina Veterinária e Zootecnia.13(1): 7-17.

15 Lefkaditis M.A., Koukeri S.E. \& Mihalca A.D. 2009. Prevalence and intensity of Otodectes cynotis in kittens from Thessaloniki area, Greece. Veterinary Parasitology.163(1): 374-375.

16 Lucas R., Jorge F.Z. \& Shiguemoto L. 2003. Uso do imidaclorprid no tratamento de otoacaríase em carnivoros domésticos. A Hora Veterinária. 23(134): 11-15.

17 Mendes-de-Almeida F., Crissiuma A.L., Gershony L.C. \& Willi L.M.V. 2011. Characterization of ectoparasites in an urban cat (Felis catus Linnaeu, 1758) population of Rio de Janeiro, Brazil. Parasitology Research. 108(1): 14311435 .

18 Medleau L. \& Hnilica K.A. 2003. Dermatologia de Pequenos Animais - Atlas Colorido e Guia Terapêutico. São Paulo: Roca, 383p.

19 Miller J.R., Griffin C.E. \& Campbell K.L. 2013. Muller \& Kirk's Small Animal Dermatology. 7th edn. St Louis: Elsevier, 938p.

20 Moriello K.A. \& Diesel A. 2011. Manejo Médico da Otite. In: August J.R. (Ed). 6.ed. Medicina Interna de Felinos. Rio de Janeiro: Elsevier, pp.348-358.

21 Norsworthy G.D., Crystal M.A., Grace S.F. \& Tilley L.P. 2004. O Paciente Felino. 2.ed. São Paulo: Roca, pp.248252.

22 Rodriguez V.R.I., Ortega-Pacheco A., Rosado-Aguilar J.A. \& Bolio G.M. 2003. Factors affecting the prevalence of mange-mite infestation in stray dogs of Yucatán, Mexico. Veterinary Parasitology. 115(1): 61-65.

23 Saridomichelakis M.N., Farmaki R., Leontides L.S. \& Koutinas A.F. 2007. An etiology of canine otitis externa: a retrospective study of 100 cases. Veterinary Dermatology. 18(1): 341-347.

24 Souza C.P., Ramadinha R.R., Scott F.B. \& Pereira M.J.S. 2007. Factors associated with the prevalence of Otodectes cynotis in an ambulatory population of dogs. Pesquisa Veterinária Brasileira. 28(8): 375-378.

25 Souza C.P., Souza M.M.S. \& Scott F.B. 2015. Perfil clínico e microbiológico de cães com e sem otoacaríase. Arquivo Brasileiro de Medicina Veterinária e Zootecnia. 67(6): 1563-1571.

26 Souza C.P., Scott F.B. \& Pereira M.J.S. 2004. Validade e reprodutibilidade da otoscopia e do reflexo otopodal no diagnóstico da infestação por Otodectes cynotis em cães. Revista Brasileira de Parasitologia Veterinária. 13(1): 111114.

27 Thrusfield M. 2007. Veterinary Epidemiology. 3rd edn. Oxford: Blackwell Science, pp.75-80.

28 Tonelli E.A. 2010. Dermatología. Buenos Aires. Disponível em: <http://dpd.fvet.uba.ar/cartelera/00007167.pdf >. [Accessed online in April 2019].

29 Tonn R.J. 1961. Estudos sobre o ácaro da orelha Otodectes cynotis, incluindo o ciclo de vida. Annals of Entomological Society of America. 54(1): 416-521. 